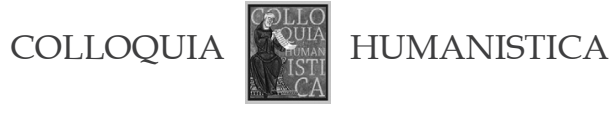

Irena Sawicka

Institute of Slavic Studies

Polish Academy of Sciences, Warsaw

\title{
A Crossroad Between West, East and Orient - The Case of Albanian Culture
}

F ven according to Albanian linguists, Albanian vocabulary is

$\perp_{\text {composed in }} 60$ percent of Latin words from different periods. The rest is Greek (old), Italian, Slavic and Turkish borrowings and, of course, a bit of lexicon considered autochthonous. It is the picture of the history of the Albanian culture. Therefore one may assume that the culture is dominated by the Western culture. In fact it is not so. At the beginning, when the Albanian written culture was crystallizing, the only foreign source was the culture coming from Italy ${ }^{1}$. Judging by the composition of the lexicon, connections with Italy (Latin) must have been long and strong and lasted many centuries. Today it is different. It does not mean, however, that the Albanian culture is dominated by Eastern influences. It remains a unique example of democracy in this matter - a true, mentally coded multiculturalism. The influence of a certain type of culture on the beliefs shared by all Albanians is connected with either a specific period in the history or a specific territory. The modern Albania inherits various influences. As a unique European society, Albanians do not define their identity through affiliation to a specific cultural (religious) circle. It is a fact. But they often refer to their Europeanness, whatever it actually means ${ }^{2}$.

\footnotetext{
1 When albanological studies were just emerging, it happened that Albanian was classified as a Romance language. Already there exists the idea of a common origin of both Albanian and Rumanian languages. The Rumanian grammar is almost identical to that of Albanian, but it may be as well the effect of later convergence within the Balkan Sprachbund (compare also the structural similarity with the Modern Greek language and Balkan Slavic languages).

2 The idea of the European integration of Albania is not a recent issue. It has its roots in the late 17 th century and early 19 th century, when the Balkans suffered under the Ottoman occupation. The liberation from this yoke was a return to freedom and the European identity.
} 
During the history, the territories inhabited by Albanians were administered by various states: Rome, Byzantium, Serbia, Venice (plus other ephemeral authorities present on the territory) and finally Turkey. Each of these brought their religion, ergo culture, science, and literary production. These overlapped with the home values determined by the tribal structures which remained in a strange pragmatic symbiosis with the foreign culture as long as it did not violate local rules. In my opinion, what determines the behavior of a modern Albanian are, to a great extent, the original native values (entrenched, among others, in the codes of clan law) and a striving for objectivism, towards Europe to which the Albanian elites have been consistently leaning. The sphere of customs, however, is full of Orient. Ethnography (music, folk costumes, ornaments, dances) combines different cultures in various proportions depending on the region and the local religion.

The West (northern Albania, the Gegs). The culture of the West is the earliest element of the Albanian high culture and writing. It came to the northern Albanian territory together with Catholic missions. The first extensive texts in Albanian are religious works written by Catholic priests. Those that we know are from the $13^{\text {th }}, 16^{\text {th }}$ and $17^{\text {th }}$ centuries. ${ }^{3}$ Also Italian missionaries wrote in Albanian. The first systematic grammar of Albanian was written in the $17^{\text {th }}$ century by Francesco Da Lecce ${ }^{4}$. On the Gegs' territory Albanian writing developed thanks to the orders of Franciscans, Jesuits and afterwards also Dominicans, who managed Catholic schools which taught prospective priests and owned the first printing presses on the territory. Albanian students often travelled to Catholic seminaries in Italy. Many of them made great careers in the church hierarchy - Albanians often became bishops, archbishops and administrators of the Catholic Church in the Balkans ${ }^{5}$.

\footnotetext{
3 These are the so-called great five: Gjon Buzuku, Mëshari (Missal), 1555, Lekë Matrënga, E mbsuame e krështerë (Catechism), 1592, Pjetër Budi, Doktrina e krështenë (Catechism), 1618 (and further issues), Rituale romanum et speculum confessionis (Roman ritual and mirror of confession), 1621, Frang Bardhi, Dictionarium latino-epiroticum, una cum nonnullis usitatioribus loquendi formulis (Latin-Epirotic (= Albanian - I.S.) Dictionary and several common phrases), 1635, Pjetër Bogdani, Cuneus prophetarum (The band of the prophets), 1685. All these works were printed in Italy. They are translations of religious texts but they contain greater or lesser original fragments. We also know about other texts which have not been preserved. There is a more than 200-pages long text from 1210 written by one Theodore of Shkodra that was discovered several years ago in the Vatican Library. We have also some texts of lesser significance. Earlier written records of the Albanian language are individual sentences or linguistic information included in the writings of Western travellers.

4 Osservazioni grammaticali nella lingua albanese (1716). Da Lecce was also the author of the Dictionario italiano-albanese dictionary (1702).

5 Among them were two authors enumerated in the third footnote: Pjetër Budi, who fulfilled
} 
The Catholic culture was, however, quite limited. It had an elite character. It developed mostly in Shkodra while the northern mountain villages could not benefit from it. It happened that local parsons did not know Albanian and heard people's confessions with the help of a translator. Nevertheless, it was the Catholic culture that gave rise to the best intellectual elite of Albania who cultivated writing in Albanian in the period when Turkish authorities and the Greek Orthodox Church victimized those who dared to write even a letter in Albanian (especially in the $19^{\text {th }}$ century). Later, Catholic priests played an important role as education and freedom activists and authors of literature. At the turn of the $19^{\text {th }}$ and $20^{\text {th }}$ centuries almost all cultural and education activists as well as authors of literature from the Northern Albania were Catholic priests.

When the Albanian literature was originating, the culture of the Italian Renaissance was mediated by Venice. The first Albanian texts were published in the printeries of Venice and Rome and thanks to the imprimatur of the Vatican's Congregation for the Propagation of Faith. Despite the influences of Venice such beautiful cities as those on the Dalmatian coast were not built in Albania. The only centres of Western culture in Albania are Shkodra and Durrës. During the Turkish invasion (and arguably earlier) many educated Albanians from the Northern part of the country left for Venice and further and they left their contribution to the European culture there, as, for example, the eminent astronomer and mathematician Jan Gazulus (Gazoli/Gjon Gazulli/Ivan Gazulić, 1400-1465), Marinus Barletius (Barletti, 1450-1465), the author of Latin works dealing also with Albanian issues or the alleged teacher of Copernicus in Padua, Leonius Thomeus (Leonik Tomeu, 1456-1531) and many others ${ }^{6}$. The first texts in Albanian were also published in Italy. They were religious in character due to the fact that those who could write were without exception Catholic priests. Moreover, only the Catholic Church owned printing offices in the $16^{\text {th }}$ and $17^{\text {th }} \mathrm{cc}$. Just like other religions present in Albania, Catholicism tried to impose the models of Latin and Italian cultures. However, contrary to the Eastern Orthodox Church and Islam, it allowed Albanian to exist in the written form. This is how the first Albanian printed texts were created. Only a few of them were preserved and are known today (cf. especially the so-called great five; see

the functions of a priest in various areas of the Balkans, and in 1599 he became the VicarGeneral of Serbia (he was also deeply engaged in the armed anti-Turkish resistance), in 1621 he became the bishop of Sapa and Sarda; Frang Bardhi (just like his uncle) was the bishop of Sapa and Sarda and the archbishop of Bar; Pjetër Bogdani was the bishop of Shkodra while his uncle - the archbishop of Skopje. Bogdani was also the administrator of the Bar archdiocese and engaged in the anti-Turkish activity.

6 It is known, e.g., that a few popes were of Albanian origin (Sylvester I, Klemens XI) and also St. Hieronymus. 
footnote 1, for details check Elsie 1995, 2005). One may risk the thesis that until the $18^{\text {th }}$ century Albanian writing was created mostly in Italy.

Apart from individual authors and Catholic activists, Southern Italy (mainly Calabria and Sicily) saw the rise of well-knit Albanian settlement ${ }^{7}$. People of this community significantly contributed to the Albanian culture and literature ${ }^{8}$. Although they are Greek-Catholics, they definitely represent a Latin, Western type of culture.

In Albania the development and popularization of the Catholic culture were inhibited by the Turkish invasion and colonization of the country. The culture of the Catholic domain played an important role again in the period of Rilindja (the National Revival, the second half of the $19^{\text {th }}$ century) - this time together with other cultural circles.

The second half of the $19^{\text {th }}$ century is the period of the late coming romanticism, the time Albanians were seeking their identity and made the first steps on the path to autonomy and then independence. The activity promoting the Albanian identity intensified after the Congress of Berlin in 1878 due to political instability. The neighboring nations who had just freed themselves from the Turkish occupation started to endanger the existence of Albanias as an integrated nation. Albanians established then an organization which gathered the representatives of all Albanian regions called the League of Prizren. First, the League worked on the administrative integration within the Ottoman Empire, but also on the mental and cultural integration. Some time later, as a consequence of the course of events, the demand for independence was formulated. In the sphere of culture at the turn of the $19^{\text {th }}$ and $20^{\text {th }}$ centuries the League acted to create a common language form (until then Albanians used various alphabets and language versions) and organize schools introducing Albanian education. At first they concentrated on the alphabet. In this area, a significant role was played by the Catholic circles. In 1908 in Monastir (present-day Bitola) a meeting of Albanian intellectuals took place which was devoted to creating the alphabet. The alphabets used until then were variations based on Greek and

\footnotetext{
Sporadic Albanian settlement in Italy was noted already in the $13^{\text {th }}$ century $(1272$, and afterwards in 1388 and 1393), but a greater scale migration took place in the $15^{\text {th }}$ century. Albanian soldiers aided Alfonso I of Aragon, the king of Naples, in putting down the rebellion in Calabria. Their commander, Demetrius Reres, was granted land in Calabria in return. His sons established the first Albanian colonies in Sicily. The true exodus, a few great migration waves, was triggered by the breakdown of the anti-Turkish resistance and the death of Skanderbeg in 1468. The last Albanian colony was established in 1774. All in all, some 100 Albanian villages and small cities were created, half of which survived until today. Most of the emigrants are the Tosks who migrated via Greece. Former Albanian ethnos living in Italy is called Italo-Albanians or Arbëresh.

8 Girolamo De Rada, a distinguished writer of Romanticism and a patriotic activist, among others, came from Calabria.
} 
Latin writing sometimes with elements of Cyrillic or Greek script as well as original creations such as the alphabet of Anonymous from Elbasan of the $18^{\text {th }}$ century which resembles a bit the Glagolitic script. During the meeting in Monastir an important role was played by the Albanian cultural-patriotic societies, a few of which were active in various parts of the Ottoman Empire (especially in Instanbul, Bukarest, Shkodra, or even Cairo). Two of the societies which put forward their proposals were from Shkodra: Bashkimi (Community, Unity) and Agimi (Dawn, Daybreak). Apart from their proposals of the alphabet, one more was given by the so-called Istanbul Society ${ }^{9}$. All three alphabets were based on the Latin writing. Finally, (at the next congress of Monastir) the "Bashkimi" alphabet prevailed. The intellectuals from Shkodra played an important role in establishing the common literary form for both Albanian languages/dialects: Gheg and south Tosk $^{10}$. It was mainly the Literary Commission (Komisia letrare 191617) that worked under the auspices of the Austrian Kultusprotektorat ${ }^{11}$.

In Shkodra, the first Albanian press was printed and it was the Catholic press. Priests supported every expression of culture, the press, education and also the theater. Finally, it should be stressed that until the $19^{\text {th }}$ century almost all Albanian printed texts were in the Gheg language, ergo they came from the Catholic cultural circle and their authors were solely priests ${ }^{12}$.

East (southern Albania, the Tosks). The culture of the East is represented by the Orthodox Church which held supremacy over the believers in the southern Albania. The influences of the Greek culture were very strong throughout that time (even the main state emblem, just like in Russia,

\footnotetext{
9 Bashkimi was led by a great Albanian culture activist and the most notable poet and writer, priest Gjergj Fishta, referred to as the Albanian Homer. He was the author of, among other things, the most beautiful work of Albanian literature: "The highland lute" (Lahuta e malciis). Agimi was led also by an outstanding Catholic writer Ndre Mjeda, while the Istanbul Society was chaired by Sami Frashëri.

10 Gheg (North) and Tosk (South) are two separate dialect complexes that significantly differ in their structure. Each of them formed its own literary tradition. Until the $18^{\text {th }}$ century writing was dominated by Gheg. Gheg literary norm survived in Kosovo until 1972. Tosk became well adopted by the literary tradition only in the 19th century. Modern Albanian norm introduced in 1946 is based on Tosk, which may have resulted from the fact that Enver Hoxha was from the South. After 1992 in Shkodra an attempt was made to bring back the old norm. Besides, it is still in everyday colloquial use both in Shkodra and Kosovo.

11 Kultusprotektorat is a right to protect, supervise and help the Catholic circles, which AustroHungary gained from Turkey in a series of treaties. The Literary Commission was headed by Gjergj Fishta.

12 For more details on the subject, see Elsie 1986, 1985, 2004-5; Szczepański 2007, see there for other sources.
} 
was a two-headed Byzantine eagle $\left.{ }^{13}\right)$. The very strong Greek culture did not weakened despite the Turkish invasion. On the contrary, one may assume that it got stronger and lost the tolerance to foreigners whom it simply ignored. The role of the Orthodox Church in shaping the Albanian culture is therefore quite ambiguous. The Orthodox Church did not support writing in Albanian; what is more it did not allow any expression of Albanian aspirations and persecuted those believers who dared to write in Albanian - it was assumed a heresy. On the other hand, however, it resisted Islamization more effectively than Catholicism, brought civilization and was versatile, offering its own high culture, a high (at that time) standard of education which Albanians made use of. The wealthy often studied in Greece. In the $19^{\text {th }}$ century there was a widely-known Zosimaia gymnasium in Janina, among whose students were many famous figures of the Albanian culture. The graduates of Zosimaia were erudite persons and polyglots. Educated Albanians from the South knew Greek, western and oriental languages. They used the Greek alphabet also when writing in Albanian.

In southern Albania the most important cultural-education centres of the $18^{\text {th }}$ and $19^{\text {th }}$ centuries were Korçë and Voskopojë ${ }^{14}$.

It should be mentioned at this point that the Greek territories of Çameria ${ }^{15}$ are an autochthonic Albanian area and the Greek minority lives also in southern Albania. Apart from that, beginning from around the $10^{\text {th }}$ century, Albanians started to migrate to Greece in waves (replacing also the vanishing Slavic ethnos). The reasons for their settling in were various: some were migrants, others won the land in a battle, as hired soldiers ${ }^{16}$ and farm workers (stratiots), and still others came periodically to earn money (in the so-called kurbet) and so on. Albanian settlements are present even today in different places in Greece. In the mid-19 ${ }^{\text {th }}$ century some $1 / 5$ of the Greek population was Albanians. The old town in Athens is called Plaka (Albanian for 'old'). Intense hellenization started in the $19^{\text {th }}$ century.

While the $17^{\text {th }}$ century was marked by the development of the religious,

${ }^{13}$ It became mythologized by combining the symbol with a folk legend, see also the folk etymology of the name Shqipëria as referring to shqiponja ('eagle'), although the only probable origin of the word is from shqip, shqipoj ('I pronounce, speak').

14 Voskopojë (Moschopolis) is an Arumanian city, the biggest town in Albania at that time and one of the biggest in the Balkans (around 20000 inhabitants), was the center of urban culture and trade point. In the $18^{\text {th }}$ century in Voskopojë there were 24 orthodox churches, a hospital, orphanage, library and Greek printing house, as well as a university called the "New Academy" - a kind of science center established in 1744. Numerous Greek teachers thought there. In the second half of the 18th century Voskopojë was attacked and looted several times and as a result lost its position.

15 Çameria was joined to Greece in 1913 after the second Balkan war.

16 In the history of hiring soldiers the Albanian tribe of Suliots outstood. It was known of its combativeness. Their commander Marko Boçari, was the author of the dictionary of this nonexistent today dialect. 
Catholic writing in the history of the Albanian culture, the $18^{\text {th }}$ century might be considered the time when the South entered the stage. A number of texts written in the Greek alphabet were created then. Voskopojë developed dramatically in the period. In the $19^{\text {th }}$ century the intensively developing Romanticism, the national liberation movement and the activities to define one's own identity saw an equal participation of both the activists from the Catholic culture circles from Shkodra and those from the South - orthodox and also the followers of Islam.

It is sometimes believed that a nation has the language form capable of functioning as a literary language only when the Bible is translated into it. At the time when the form of literary language and the alphabet were intensively thought over, such a translation was made by Konstantin Kristoforidhi (1826-1895) ${ }^{17}$ from the South of Albania. He did not try to accommodate the two Albanian languages/dialects, but translated the New Testament into both (Gheg in the Latin alphabet and Tosk in the Greek alphabet). He did not use specific dialects but super-dialectal forms aspiring to general forms.

When discussing the contribution of the orthodox society to the Albanian culture, one cannot ignore the "red bishop" Stylian Fan Noli man of many talents (he was an actor, musician, cantor and musicologist, historian ${ }^{18}$, writer, orthodox priest, excellent translator, publisher of emigration magazines and political and democracy ${ }^{19}$ activist). Fan Noli was the Prime Minister of the only democratic government in the interwar period (1924) and the establisher of the Albanian Autocephalous Orthodox Church (1937).

Orient. The oriental culture left its imprint on the Albanian culture and customs. It was brought by the Turkish occupation, but started to integrate only at the time of intense islamization in the $18^{\text {th }}$ century. When it comes to the attitude of the Turkish authorities to the local culture, it was exactly the same as the attitude of the Greek Orthodox Church. Similar to Greece, Turkey offered good education in the schools of Istanbul, from which benefited in the $19^{\text {th }}$ century mainly Albanians from the South ${ }^{20}$.

The Albanian cultural studies put forth the thesis of Crypto-Christianity. It states that Albanians converted to Islam for purely pragmatic reasons,

17 It was not the very first translation, but the first one into both Albanian languages.

18 He gained his $\mathrm{PhD}$ in the United States with his dissertation devoted to Skanderbeg.

19 Inter alia he made a success in the League of Nations.

20 Earlier young boys from various parts of the country were taken from their families and educated to become janissaries in Istanbul. Afterwards they became an important element of the Turkish elites. Also Skanderbeg got to Istanbul in this way. 
becoming Muslims only from the formal point of view. In secret they remained Christians. I do not know actually what to think about it. I have an impression that for Albanians, in general, religion is mainly a form and that they accept it easily (they even practise various religions at the same time - one formally and the other in private), while remaining a society that respects its own traditional values. As to faith they are indifferent. A characteristic case is that of the Has tribe (they live in the mountains on the Albanian-Kosovo border) who bring up girls to be Catholic while boys - Muslims.

Despite the negative role of the Orient implied by the Turkish bondage and repressing the local culture, the culture of the Orient played a positive role by enriching the Albanian culture and literature. It brought new forms into the literature, a different, very sensual, way of reception, and different contents. Because of the Turkish mediation, Albanian literature had an opportunity to use classic models of Persian, Arab and Azeri literatures. In the second half of the $18^{\text {th }}$ century and in the $19^{\text {th }}$ century the bejtexhin literature was popular (literature of the aljamiado type). These are Albanian texts written with the Arab alphabet - religious and love (or even erotic) literature (typical oriental forms of poems, such as divans, gazels, mesnevis, mevluds, machmuas, qasidas and other) as well as tales (love and moralistic), based on the motives from Koran, and also historic eposes with the most popular about the history of Shiism, and especially about the battle of Kerbela (in 680), in which the Shia imam Hussain, the grandson of the Prophet Mohammed ${ }^{21}$ was killed. It was an elite literature. Only those who knew the Arab alphabet and understood many orientalisms were able to read it. It is the part of the Albanian culture that still awaits scientific interpretation. Many of those works remain in manuscript form in private collections and some are lost. Critical studies of such works require not only the knowledge of Albanian but also Arabic, Persian and Turkish, including archaisms of all these languages.

Today Islam is formally the dominating religion in Albania and Kosovo. It contains, however, a specifically Albanian element, namely the Bektashi sect with which Albanians identify in a special way. Although most practitioners of Islam in Albania are Sunni, the numerous Shiite sects are relevant to the problem of identity, most importantly the Bektashi who found their asylum in Albania not by accident ${ }^{22}$. The Bektashi doctrine, which waives

\footnotetext{
${ }^{21}$ The battle of Kerbela is described in the following pieces: Dalipa Frashëri Hadikaja (The garden), Shahina beya Frashëri Myhtarnameja (The tale of Myhtar), Naima Frashëri Qerbelaja (Kerbela).

22 The sect was created in Turkey in the $13^{\text {th }}$ century and spread to the Balkans from there. In 1925 it was banned in Turkey as a heresy and moved its headquarters to Tirana (for details, see
} 
many bans of the orthodox Islam, understands god in a transcendental manner, is tolerant and open to all other faiths, with sources both in Islam and Christianity, perfectly matched the Albanian religious indifferentism. Similar to Albanians, the sect followed thoroughly the fixed ritual. Although it is not the dominant sect in Albania, they cherish it with care.

At the turn of the $19^{\text {th }}$ and $20^{\text {th }}$ centuries the factor of faith seemed the most important when it came to recognizing the national affiliation of neighbours (compare the Croatian-Serbian case). Although it was clearly impossible for Albanians to base their identity on faith, this idea accompanied them during the period of Rilindja. Since other nations, after freeing themselves from the occupant's power, not only in the Balkans, built their identity mainly on the very factor, some Rilindja activists thought that a national faith is indispensable.

In such a situation the only choice seemed Bektashism, since many activists of Rilindja from the South were Bektashi (among them were the leaders and fathers of the League of Prizren, the Frashëri brothers: Abdyl - a politician, Naim - a national poet and writer, and Sami - a scientist ${ }^{23}$ ). The idea of recognizing Bektashism as the national religion was put forward by Naim Frashëri ${ }^{24}$. In a sense it did become a true national religion ${ }^{25}$, though quantitatively Bektashism gives way to other denominations in Albania and at present it is experiencing a revival in Turkey.

Modern national identity of Albanians is built on the hypothesis of the Illyrian origin ${ }^{26}$, tradition (including the elements of customs and values included in tribal codes), the language that is distinct in comparison to all other languages, the cult of great figures with Skanderbeg in the first place, representing the Catholic circle of culture although he was brought up at the sultan's court in Islam faith. However, later on, he returned to his native faith and turned against Turkey. In Europe he was famous for defending Christianity and became the hero of numerous literary works. Pope Callixtus III gave him the title Atleta Christi. During the period of Romanticism he became present in the world literature again as a romantic

\footnotetext{
Elsie 2001: 25-34).

23 Sami Frashëri as the only one of the brothers is not buried in Albania, but in Turkey. He was a distinguished Encyclopaedist who rendered great service not only to the Albanian culture but mostly to the Turkish culture. Naim and Sami wrote numerous texts in Albanian, Turkish, Greek, Persian, and French. Naim is the author of the national epos Bagëti e bujqësija.

${ }^{24} \mathrm{He}$ is the author of, inter alia, Fletoret e Bektashinjet, (Bektashi notebooks), which provide extraordinary insight into the beliefs of the sect.

25 Compare the construction of the Bektashi tekke (lodge) in the centre of Tirana; in 1991 a committee for the revival of the Bektashi community in Albania was established,

${ }^{26}$ It is a controversial thesis, competing with other ideas.
} 
hero fighting to free his nation. I assume that today the person of similar value to Albanians is Mother Theresa.

The figure of Skanderbeg present in the Albanian culture was created by the Arbëreshes. The first one to introduce his deeds in literature was Marin Barletti (Barletius) in the Latin work of 1504 titled De obsidione Scodrensi 'On the siege of Shkodra'. Later Skanderbeg or the events connected with him were a common subject of Albanian literature. The most important among the literary works are: Scaderbeccu i pa-faan (Misfortunate Scanderbeg) by Girolamo De Rada, Kënka e sprasme e Balës (The last lay of Bala) by Gavril i Ri, Istori' e Skenderbeut (The Story of Skanderbeg) by Naim Frashëri, a poem Vorri i Skanderbrgut (Scanderbeg's grave) by Ndre Mjeda (in: Poesie e poemi), Historia e Skenderbeut (The Story of Skanderbeg) by Fan Noli, a novel Kështjella (The castle) by Ismail Kadare, and other works.

The problem of the Albanian origin first appears in the texts of the Arbëreshes (because it was impossible to connect Albanians with any other ethnos living in the Balkans today, the Pelazgic, Macedonian and Epirotic origins were considered). The current thesis on the Albanians originating from the Illyrians is quite convenient and non-conflicting - it ensures the territorial continuity and sanctions the presence of Albanians on the territory they currently occupy. Scientific (linguistic) arguments supporting the thesis were provided by a Polish Albanologist and Indo-Europeanist, who pinpointed a certain absolutely unique, as far as Indo-European languages are concerned, similarity of some phonetic reflexes between the Albanian and Illyrian languages ${ }^{27}$. The thesis was presented by Wacław Cimochowski at the Illyric congress in Tirana in 1972. Since then he has become almost an Albanian national hero. Albanians' attitude towards the thesis on the Illyrian origin is absolutely uncritical. They do not accept different hypotheses even though the one recognized by them is at least arguable and absolutely impossible to verify - practically nothing has been preserved from the Illyrian language, only some names of rulers and one sentence probably in Illyrian, the content of which is hard to determine ${ }^{28}$.

The factor of language distinctiveness was sanctioned in an important patriotic poem from the Rilindja period (1878) written by poet Pashko Vasa O moj Shqypni (Oh Albania, poor Albania ${ }^{29}$ ), in which he wrote "feja e Shqyptarit asht shqyptaria" (the faith of the Albanian is Albanism!) ${ }^{30}$.

\footnotetext{
27 Albanian is unique when it comes to the division of languages into Centum and Satem languages. As the only Indo-European language Albanian may be described as Satem-Centum.

28 Compare Bednarczuk 1986.

29 English titles were taken from those works that exist in English translation.

30 Below is the relevant excerpt of the poem:

Çonju, shqyptar, prej gjumit çonju,
} 
The poem was published for the first time by Jan Jarnik in 1881 .

Nowadays the Albanian national identity is devoid of religious context. This is also how I perceive the Albanian culture, in which religious elements constitute a superficial component of purely ethnographic character. Albanians attach greater importance to traditional values connected with the medieval clan law (besa 'a word, a promise of keeping the word, commitment', honour, the cult of a visitor, clan vengeance, the institution of a sworn virgin and so on $)^{31}$. I dare to say that Albanians have, in a sense, a double identity - national and tribal, especially those from the northern, mountainous territories. If the element of religion occurs, it is only because commonly whole clans practise one religion. The so-called "national holy things" are heterogenic elements. Some of them seem in a way created, such as the myth on the origin of Illyrians (a very uncertain hypothesis) or the Albanian eagle (Byzantine). They emerged due to the "national" need and their birth is already familiar to us. What is authentic, however, are the building blocks of the tribal culture - the clan's memory. But even the origin of the most famous clan law the Code of Lekë Dukagjini is doubtful ${ }^{32}$.

In my opinion, the quintessence of being Albanian is what we find in the already mentioned post-Romantic poem by Gjergj Fishta (1871-1940) Lahuta e malcis (The highland lute). The poem was written in the short interwar period, the only time before 1992 that guaranteed freedom of speech. In this short period of time in Albania the literature of European character started finally to develop, tentatively and with great delay referring to European trends. The literature was produced with the contribution of the writers from the South of Albania, but Catholic authors (mostly priests) from the North were in majority. For the first time émigrés and emigrant periodicals in Western Europe and the United States became involved in the eruption of literary, cultural and educational activity. The period marked with Western culture (mainly Catholic) continued successfully in

\footnotetext{
Të gjith si vllazën n'nji bes shtrëngonju,

E mos shikjoni kish e xhamija,

Feja e shqyptarit asht shqyptarija!

[Awaken, Albania, wake from your slumber,

Let us all, as brothers, swear a common oath

And not look to church or mosque,

The faith of the Albanian is Albanism!] (translated by Elsie 2005: 88).

${ }^{31}$ It happens still today that the court gives a lighter sentence for a murder if the perpetrator defends by evoking the order of clan vengeance.

32 It is the only code of clan law that exists in a written form (it was written down by priest Gjeçovi and published in 1933). Other codes are known in oral form. Albanians give the name of the code after the Medieval Albanian prince Lekë from the Dukagjin clan. It is probable, however, that the name was mistakenly associated with the Latin expression Lex Dukagjini (The Dukagjin's Law), when it appeared in the $19^{\text {th }}$ century scientific texts of Austrian researchers.
} 
the period of the Italian occupation during the Second World War. Just after the war, the Catholic circles from Shkodra were repressed. Most of them lost their lives in communist camps and prisons. Also Gjergj Fishta did not survive, accused of anti-Slavic elements in his literary output. This absurd accusation was formulated during the tight Albanian-Yugoslavian co-operation and when plans were made to incorporate Albania into Yugoslavia $^{33}$. The accusation was based on one of the elements of The highland lute's content, namely the fight between Montenegrins and Albanians for borderlands ${ }^{34}$.

The content of The highland lute is based on real events, such as the fights between Montenegrins and Albanians, the Prizren League of 1878, its collapse and the repressions that followed, Balkan wars; there appear authentic figures, and not those known from the history or culture, but common highlanders, shepherds $s^{35}$, combatants, who were honoured in this way by the author in gratitude for their will to share with him the folk culture. Folk beliefs, customs and tribal law, mythology and even forms of oral literature became, together with real historical events, an inspiration to writing The highland lute. The poem is written in octosyllabic verse characteristic of Albanian historical epics. In The highland lute one may find figures from Albanian mythology and legends, such as oras (female spirits whose very name is often taboo), lugats (vampires), shtrigas (witches), kulshedras (dragons) and drangues (semi-human figures with wings). In The highland lute oras gather on the top of one of the mountains, just like gods on Mount Olympus, and determine the fate of battles, interfere in events. At some point the main Great Ora starts the fight to death with the Montenegrin Nymph of similar rank. Researchers of literature see here also inspirations from Greek mythology. Moreover, The highland lute contains all elements of the clan law that may be found in the most famous code - Kanuni Lekë Dukagjini: funeral customs, rules of hospitality, family vengeance, honour and besa, the ritual described precisely in the Kanun.

\footnotetext{
33 At that time one of the obligatory courses at school was the Serbo-Croatian language course.

34 At the same time a great community of culture and customs of Montenegrins and Albanians from the North is observed. It is often interpreted as the common Balkan culture. The relevant elements of the culture (customs, mythology, folk art - common forms and motifs, ethnographic elements, etc.) are preserved as live only in the western Balkans, but the connection between Northern Albania and Montenegro is much stronger, especially in the area of the tribal law structure.

Today the borderlands both in Montenegro and Albania are ethnically mixed. Some Albanian families living in Montenegro or Montenegrin ones in Albania have denationalised while some others remember their origins. Most of them, however, cultivate their language and traditions. 35 In his papers on Albanian literature, Robert Elsie reproduces even authentic photographs of Oso Kuka, Marash Uci, Tringa and others).
} 
Elements of clan traditions appear in numerous Albanian literary works. The problem of besa was present even in the Turkish play by Sami Frasheri Besa yahud ahde vefa (Pledge of honour, an Albanian tragedy), devoted to a tragic dilemma of an Albanian father who chooses to kill his own son in order not to break besa.

Albanian mythology, folk legends and songs became subjects of interest and themes of literature only in the $19^{\text {th }}$ century and mostly at the beginning of the $20^{\text {th }}$ century, that is in the period of the late-coming Romanticism (earlier there existed only religious and historical literature). Collecting folk art was popular among the Arbëreshes. Among south-Italian authors Girolamo De Rada should be enumerated. He wrote, among other things, epics based on Albanian folk mythology known as Canti di Milosao (Songs of Milosao) and Serafina Thopia. Arbëresh authors include also Gabriele Dara the Younger (Gavril Dara i Ri), whose Kënka e sprasme e Balës (The last lay of Bala) illustrates not only the Romantic fashion but also expresses the most important Albanian values. The work, similar to Ossian songs in that it was introduced to the literature as a relic of medieval literature, tells the story of an Arbëresh, the highlander bard Bala, who misses his native Balkans at which he looks from the mountain tops across the sea. Bala tells the story of Nik Peta and Pal Golemi, Albanian warriors for freedom from the Skanderbeg's period.

In Albania, the short period of peak development of modern literature (post-Romantic, naturalistic, modernistic) was soon replaced by the obligatory social realism which ruled for more than 50 years. After its collapse, some very interesting poetry and prose began to develop, which to some extent refer to the contents characteristic of the literature from the pre-communist era.

The author who uses those elements present in The highland lute the most is Ismail Kadare, an eminent contemporary Albanian writer (and poet). He is a proponent of the thesis on the affinity of the Albanian mythology to the Greek one. He often uses, rather as requisites, elements of the Greek mythology ${ }^{36}$. Albanian elements from legends appeared in many of his novels. In the Kush e solli Doruntinën (Doruntine) he uses the legend about Constantine who rises from the grave in order to keep his word (besa). The novel Ura me tri harqe (The three-arched bridge) is based on the myth of the immuring a living person in a building (the most famous is the variant on the Rozafa castle). Prilli $i$ thyer (Broken April) is a dismal account of a family vengeance, which also presents other elements of the clan law (Kanun). The same motif was used in the novel Lulet e ftohta të

36 Përbindëshi, 1991 (The monster - a Trojan horse is meant), Piramida (Pyramid), 1993. 
marsit (Spring flowers, spring frost), which incorporates a folk story about a girl forced to marry a snake. Nepunësi $i$ pallatit te ëndrrave (The palace of dreams) makes us of the theme of guslars presenting folk epics, while Krushqit janë të ngrirë (The wedding procession turned to ice), contains the mythological motif of oras changing a wedding procession into ice. Dosja $H$ (The file on $\mathrm{H}$ ) is about the fascination of two American ethnologists with Albanian folk epics (they are authentic figures - researchers who collected folk materials in the Balkans in the early $20^{\text {th }}$ century ${ }^{37}$ ). The novel Shkaba (The eagle) retells a dark ancient legend about an eagle which can take you wherever you want on condition that you feed it with meat (your own flesh) during the flight. The publication Tri këngë zie për Kosovën (Elegy for Kosovo), a collection of three short stories, refers to the Battle of Kosovo Field, which is an important element of Albanian folk epics (as well as Serbian). These are undoubtedly the best works of the author.

The best Albanian contemporary literature and film often contain some characteristic elements that contribute to the atmosphere of the works (they might have their source in the tribal structures and mythology). These are, generally speaking, some dark, gloomy climates: certain determinism and pessimism, sadness imparted by a gloomy landscape, bad weather (mud, rain, dark sky). Rain, clouds and mud are metaphors typical of Kadare's literature (as Robert Elsie puts it: it is about the contrast with the joyful and sunny climates present in the literature of social realism (Elsie 2005: 136) - I think it is rather about the Albanian spirit). I find the same elements, although without weather-related props, in the prose of possibly the best modern author Fatos Kongoli ${ }^{38}$. Such moods have always been present in Albania - the misery and determinism of a tribal society, the necessity to subject to death in young age (family vengeance), the lack of opportunities in choosing one's way of life, especially harmful to women (death penalty for infidelity and the resignation from femininity in the case of sworn virgins); the permanent threat of camp imprisonment or death in the communist Albania, the poverty and lack of perspectives after gaining independence from the regime. All this was perfectly pictured in such films as: Putkownik Bunkier (Colonel Bunker), an Albanian-Polish production, starring Anna Nehrebecka as the main character, L'America, an Italian production with Michele Placido, Tirana zero, made by Albanians, or the Greek production Eduard.

\footnotetext{
37 Albert Lord and Milman Parry, about their collection see: http://chs119.chs.harvard.edu/mpc/.
}

38 E.g. in I humburi (The loser), Kufoma (The Corpse), Lëkura e qenit (Dog's skin) and other. 


\section{References}

Barletius M.

(1504) De obsidione Scodrensi, Venice.

Bednarczuk L.

(1986) „Języki starobałkańskie”, [in:] Języki indoeuropejskie I, Warszawa, pp. 469-513.

Da Lecce F.M.

(1702) Dictionario italiano-albanese.

(1716) Osservazioni grammaticali nella lingua albanese.

Dara i Ri G.

(1906) Kënka e sprasme e Balës, Catanzaro.

De Rada G.,

(1836) Poesie albanesi del secolo XV. Canti di Milosao, figlio del despota di Scutari, Napoli.

(1839) Canti storici albanesi di Serafina Thopia, moglie del principe Nicola Ducagino, Napoli.

(1872) Scanderbeccu i pa-faan, Corigliano Calabro.

Elsie R.

(1986) Dictionary of Albanian literature, Westport.

(1995) History of Albanian literature, 2 volumes, New York.

(2001) A dictionary of Albanian religion, mythology, and folk culture, New York.

(2004-5) Zarys historii literatury albańskiej: vol. 1 („Bibliografia literatury albańskiej”), vol. 2 („Narodziny literatury albańskiej, wiek XV-XVII”), vol. 3 („Albańska literatura wieku XVIII i XIX”), vol. 4 („Współczesna literatura albańska”), Toruń.

(2005) Albanian literature, A short history, London - New York.

Fan Noli T.S.

(1921) Historia e Skenderbeut, Boston.

Fishta G.

(1923) Lahuta e malcis, Shkodra.

Frashëri D.

(1842) Hadikaja, unpublished.

Frashëri Shahin bey

(1868) Myhtarnameja, unpublished.

Frashëri N.

(1886) Bagëti e bujqësija, Bucureşti.

(1896) Fletoret e Bektashinjet, Bucureşti.

(1898) Istori' e Skenderbeut, Bucureşti.

(1898) Qerbelaja, Bucureşti.

Frashëri S.

(1875) Besa yahud ahde vefa, Constantinople.

Gjeçovi Sh.

(1933) Kanuni i Lekë Dukagjini, Shkodra

Jarnik J.U.

(1881) Zur albanischen Sprachenkundem, Leipzig. 
Kadare I.

(1963) Gjenerali i ushtrisë së vdekur, Tirana.

(1970) Kështjella, Tirana.

(1978) Ura me tri harqe, Tirana.

(1978) Prilli i thyer, Tirana.

(1979) Kush e solli Doruntinën, Tirana.

(1981) Nëpunësi i pallatit të ëndrrave, Tirana

(1986) Krushqit janë të ngrirë, Tirana (published in the journal Koha e shkrimeve).

(1990) Dosja H, Tirana.

(1991) Përbindëshi, Prizren.

(1993) Piramida, Tirana.

(1996) Shkaba, Tirana.

(2000) Lulet e ftohta të marsit, Tirana.

Kongoli F.

(1992) I humburi, Tirana.

(1994) Kufoma, Tirana.

(2003) Lëkura e qenit, Tirana.

Mjeda N.

(1966) Poesie e poemi, Tirana.

Szczepański W.

(2007) „Znaczenie katolicyzmu dla Odrodzenia Narodowego Albańczyków i budowy przez nich własnego państwa (druga połowa XIX - początek XX w.)”, [in:] Studia z dziejów Rosji i Europy Środkowo-Wschodniej XLII, pp. 5-15.

\section{Kultura albańska - zderzenie Zachodu, Wschodu i Orientu}

Albania jest unikalnym przykładem prawdziwej, zakodowanej mentalnie multikulturowości. Wpływ określonego typu kultury na poglądy wspólne wszystkim Albańczykom związany jest bądź z określonym okresem historycznym, bądź z określonym terytorium. Dzisiejsza Albania dziedziczy różne wpływy i, jako unikalne w Europie społeczeństwo, Albańczycy nie określają swojej tożsamości poprzez przynależność do określonego kręgu kulturowego (religijnego). Współcześnie tożsamość narodowa Albańczyków zbudowana jest więc bez kontekstu religijnego. Opiera się na koncepcji pochodzenia od Ilirów, wielkich postaciach historii albańskiej, mitologii, odrębności językowej. Elementy religijne stanowią warstwę powierzchowną, czysto etnograficzną. Większą wagę przywiązują Albańczycy do wartości tradycyjnych, związanych ze średniowiecznym prawem rodowym (besa 'słowo, obietnica, zobowiązanie’, honor, kult gościa, danego słowa i in.). 


\title{
A Crossroad Between West, East and Orient - The Case of Albanian Culture
}

\begin{abstract}
Albania is a unique example of authentic mentally-coded multiculturalism. The influence of a certain type of culture on believes shared by all Albanians is connected with either a specific period in history or specific territory. Modern Albania inherits various influences. As a unique European society Albanians do not define their identity through affiliation to a specific cultural (religious) circle. Nowadays Albanian national identity is devoid of religious context. It is based on the idea of Illyrian origin, great figures of Albanian history, mythology, language separateness. Religious components make up a surface of purely ethnographic character. Albanians attach greater importance to traditional values connected with the medieval clan law (besa 'a word, a promise of keeping the word, commitment', honor, the cult of a visitor, clan vengeance, the institution of a sworn virgin and so on).
\end{abstract}

Key words: Albanian Culture, Crypto-Christianity, Bejtexhin Literature, Bektashism, Rilindja, League of Prizren 